\title{
Bányai Emőke: Az iskolai szociális munka szülőkkel, családokkal kapcsolatos feladatai, a szüloók bevonása gyerekük iskolai életébe
}

\author{
(Parents Involvement)
}

Szakirodalmi áttekintés

\section{ELÖLJÁRÓBAN}

Az iskolai és óvodai szociális segítő munkakör széles körü megjelenésével 2018 szeptemberétől egy újfajta képzési igény jelenik meg Magyarországon. Az említett munkaköröket betöltőknek definiálniuk kell szakmai szerepüket, amelyhez rendelkezésükre áll a korábban megjelent szakirodalom, az útmutatónak szánt minisztériumi szakmai ajánlás, de az újonnan alkalmazott munkatársak fogják a helyi adottságoknak és igényeknek megfelelöen kialakítani a konkrét tartalmakat.

Az iskolai szociális munka fejlett országokban több mint egy évszázadra visszatekintő tevékenység, melynek gazdag módszertani irodalma van. Ebben a cikkben ebböl szeretnék áttekintést nyújtani, egyetlen aspektusra: a szülőkkel végzett munkára szükítve a válogatást. A szakirodalmi áttekintést egy viszonylag régi és Magyarországon ismert szerző, Florence Costin definíciójának ismertetésével kezdem, mivel a rendszerszemléletű megközelítés még mindig érvényes gondolati keretet jelent az iskolai szociális munka irodalmában. A cikk további részében napjaink szakirodalmából válogatok - így jól érzékelhető lesz az a szemléleti elmozdulás, ami az iskolai szociális munka területén, elsősorban az Egyesült Államokban, illetve az Egyesült Királyságban történt.

Anthony Huffman tanulmánya arra hívja fel a figyelmünket, hogy a családformák pluralizálódásával az iskolai szociális munkás családokkal kapcsolatos feladatai is átalakulnak. Jeffrey McCabe azt a helyzetet elemzi részletesen, mikor az iskolában készül gyermekvédelmi interjú. Milyen szempontokat kell figyelembe venni abban a helyzetben, ha felmerül a gyanú, hogy a szülö vagy más családtag súlyosan veszélyezteti a gyereket? Itt az eltérö törvényi keretek miatt nem is annyira a válaszok, sokkal inkább a kérdések lehetnek elsősorban fontosak számunkra.

A fogyatékossággal vagy tartós betegséggel élö szülők támogatása abban, hogy szülőként egyenlő eséllyel vehessenek részt gyermekeik iskolai életében, szintén fontos szociálismunka-feladat, amire eddig inkább egyedi jelenségként tekintettünk, nem fogalmazódtak meg általánosabb elvárások; Stalker, Brunner, Maguire és Mitchell tanulmánya segítségével rápillanthatunk erre a területre.

Evidenciának tekinthető, hogy az iskolai szociális munkásnak fontos szerepe van az iskolai zaklatás megelőzésében. A prevenciós programok egyedi helyzetre igazítása során messzemenően figyelembe kell venni az iskola társadalmi környezetét, tájékoztatni kell a szülőket és együttmüködésüket kérni. Ezekre az eddig kevésbé tárgyalt aspektusokra hívja fel a figyelmet Brewer, Jr., Meckley-Brewer és Stinso tanulmánya.

Egyre hangsúlyosabban jelenik meg az iskolai szociális munkás tevékenységében a különféle együttmüködések elősegítése annak érdekében, hogy gyerekek, tanárok, segítők, szülők egymást jobban értve próbálják elérni közösen megfogalmazott céljaikat. Ebben a folyamatban a szerepfelfogások gyakran eltérőek - ennek jellegzetes mintázatait vizsgálja Susan I. Stone és Jessica Charles tanulmánya.

Az iskolában elkövetett súlyosabb fegyelmi vétségek büntetése sokszor az iskolából való kitiltás vagy a gyerek eltanácsolása, aminek nemcsak a gyerek, hanem a szülő, a család 
számára is nemkívánatos hatásai lehetnek. A káros következmények elkerülése érdekében az utóbbi időben gyakran alkalmaznak egy olyan, resztoratív elveken alapuló módszert, melyben „kortársak bírósága” dönt arról, hogy egy fegyelemsértésnek milyen következményei legyenek. Egy ilyen eljárás bevezetése komoly előkészítő munkát igényel mind az iskola munkatársai, mind a gyerekek, mind a szülők vonatkozásában. Katie Cotter Stalker tanulmánya ezt mutatja be.

\section{FLORENCE COSTIN (1975) - A iskolai szociális munka definíciója}

Costin iskolai szociális munka definíciójának újdonsága az 1970-es években az volt, hogy a rendszerszemléletet az iskola viszonyrendszerére is kiterjesztette. Már az 1960-as évektől az Egyesült Államokban a szociális munkások a tanulókkal kapcsolatos problémákra nem úgy tekintettek, mint ami a gyerek vagy szülei tulajdonságaiból fakad, nem az ő rossz és megjavítandó múködésükön volt a hangsúly, mint korábban a klinikai modellben. Az iskola, a gyerek, a szülők, a lakóközösség és más érintett szereplők között kialakuló problémákat kezdték úgy értelmezni, hogy azokat a gyerekek és a családok jellemzői, valamint az iskolai és a lakókörnyezeti feltételek együttesen állítják elő. Costin szerint sok iskolai szociális munkás ragaszkodott a hagyományos klinikai modellhez, mely a gyerekek és a családok megváltoztatását tartotta elsődlegesen fontosnak, de a gyerekek csavargása, az iskolából való kimaradás, a tanulók alacsony teljesítménye meggyőzte őket is arról, hogy az iskolagyerekek-szülők viszonyrendszerében értelmezhető a probléma, ott kell valamit megváltoztatni. Korábban az Egyesült Államokban leggyakrabban akkor fordultak a pedagógusok iskolai szociális munkáshoz, ha egy gyerek visszahúzódó volt, agresszíven viselkedett, nem talált barátokat, iskolafóbiás volt, nagyon boldogtalannak látszott vagy bomlasztóan viselkedett. Ezeket a jelenségeket egyéni problémák tüneteinek tartották.

Ezzel szemben a gyerekeket, az iskolát és a lakóközösséget is figyelembe vevő megközelítés az 1960-as évektől elkezdett inkább arra figyelni, hogy milyen hiányosságok vannak az iskolában, ill. a lakóközösségben, milyen nehézségekkel küzdenek a problémásnak tekintett gyerekek életük egy adott pontján, tehát a fókuszba inkább a közösség, mint az egyes gyerek került. Ettől kezdve az iskolai szociális munkás nem az egyént tekintette a probléma forrásának és nem is az iskolát, ami túl sok alacsony teljesítményü gyereket 'termel' (ez volt az ún. iskolaváltoztató modell). Ettől kezdve inkább azok az ismétlődő minták kerülnek a fókuszba, amiért a gyerekek egy része csavarog, kimarad az iskolából vagy rosszul teljesít, mivel az iskola nem találja meg a megfelelő módot arra, hogy ennek a csoportnak az oktatási szükségleteit kielégítse. Ez persze nem jelenti azt, hogy az egyes gyerek adottságait, szükségleteit nem kell figyelembe venni, hanem úgy tekintenek ezekre, mint amik a többi, fent említett tényezővel kölcsönhatásban állnak.

Az e modellt támogató elméletek között Constin (1975) kiemeli a szociális tanulás elméletét, amely azt hangsúlyozza, hogy a gyerekek modellkövetéssel, utánzással tanulnak, a társadalmi szerepek követelményeket és elöírásokat támasztanak az egyénnel szemben, és a kultúra nagy hatással van az egyes gyerekre. Ez az elmélet hangsúlyozza, hogy a tanulás folyamatosan történik az egyén életében.

A rendszerelmélet szintén alátámasztja ezt a megközelítést. Eszerint az egyes tényezők nem külön-külön, hanem rendszert alkotva, egymással való összefüggésükben hatnak. A rendszernek meghatározott struktúrája van, melyet a változó körülmények között is 
fenntartunk. A rendszer koherens módon müködik: bármely részének változása kihat az egészre.

Az iskola rendszerként müködik, amelynek részei a gyerekek, az iskola munkatársai, a szülők, a lakóhelyi közösség képviselöi; a köztük levő kapcsolatok adják a kohézióját. Az egyes gyerekek viselkedését a rendszer egészének kontextusában kell értelmezni. Az iskolát külső rendszerek veszik körül, melyek pl. szabályozások vagy a rendelkezésre álló források szempontjából érintik az iskola életét. Szintén fontos, hogy milyen összetételü népesség lakik az iskola környezetében, milyen ennek a közösségnek a kultúrája, hatalmi struktúrája stb. Ezek a tényezők az iskolával szembeni nyílt vagy rejtett elvárásokat is meghatározzák és az eredményességét is befolyásolják. Az iskola - mint minden rendszer - alrendszerekből áll, melyek olykor hierarchikusan kapcsolódnak egymáshoz.

A felmérés (assessment) ebben a modellben nemcsak a gyerek vagy a család vonásaira terjed ki, hanem arra is, hogy a gyerek egyéni adottságai, családi háttere milyen kölcsönhatásban áll az iskola és a lakóközösség lehetőségeivel, kihívásaival. Egy ilyen felmérésben a közösség demográfiai jellemzői, a helyi források (szakrendelések, könyvtár, nyári programok) szerepelnek, illetve bármi olyan tényező, mely fontos az adott közösség számára. Fontos megismerni, hogy az egyes szereplök mit tekintenek problémának, az oktatási folyamat melyik eleme okoz feszültséget, stresszt; és melyek a jó érzéseket okozó aspektusai. Fontos megérteni, hogy az iskola mit vár a szülöktől, milyen segítő szolgáltatások müködnek helyben. A felmérés során fontos beazonosítani a leggyakrabban előforduló problémahelyzeteket és azt, hogy ez a gyerekek egyéni életciklusának és iskolai pályafutásának mely pontjain jelennek meg. Ha az iskolába frissen belépő gyerekek különféle okoknál fogva nincsenek készen arra, hogy becsatlakozzanak az iskola életébe, a szülők nem értik, hogy mit kéne tenniük, az biztosan egy olyan helyzet, amellyel az iskolai szociális munkásnak foglalkoznia kell. Az iskolai szociális munkában hagyományosan az iskola munkatársai, a szülők, gyermekvédelmi szervezetek együttesen alakítják ki az együttmüködési tervet. Ezt minden esetben felmérés és számos konzultáció előzi meg az érintettekkel.

Azt gondolom, hogy ez a megközelítés nem vesztette érvényét: a rendszerszemléletü megközelítés ma is hasznos szemléleti fogódzókat ad a mindennapi munka során, hozzásegít ahhoz, hogy a különféle helyzetekben szerzett tapasztalatokat átfogó keretben értelmezhessük és ennek megfelelően tervezzük a beavatkozásokat.

Az 1970-es évek óta azonban a fejlett országokban olyan társadalmi jelenségek játszódtak le, melyek szükségessé teszik, hogy az iskolai szociális munka mint szakma, újradefiniálja magát. Melyek ezek a változások?

ANTHONY M. HUFFMAN (2013) - Az iskolai szociális munka szerepének változása a családformák átalakulásával kapcsolatban

Anthony Huffman szerint a családok átalakulása olyan folyamatokat indított el, melyben gyerekek tömegei kerültek abba a helyzetbe, hogy családjuk sérülékenysége miatt erösebb külső támogatásra van szükségük; így az iskolai szociális munka egyik fö feladata ezeknek a családoknak a megerősítése. Huffman helyzetleírása meglehetősen sarkos, azokra a hiányokra hívja fel a figyelmet, melyekkel az egyszülős családok szinte törvényszerüen 
küzdenek. Azok a jelenségek, melyeket leír, hazánkban is megfigyelhetőek, így az általa megfogalmazottakra véleményem szerint mindenképpen érdemes odafigyelnünk.

A válások számának emelkedésével, az együttélések, az egyszülős családok arányának emelkedésével nőtt azoknak a gyerekeknek a száma, akik kevésbé stabil családokból, kevesebb családi támogatással érkeznek az oktatási rendszerbe. Huffman szerint a szülők családi állása és a gyerek iskolába járása, fegyelmezettsége, iskolai teljesítménye között statisztikailag erős összefüggés mutatkozik: az egyszülős családok esetében magasabb arányban van probléma az említett területeken, a családi stabilitás hiánya előre jelzi a veszélyeztetettséget. Az ilyen családoknak külön segítségre van szükségük, melyet az iskolai szociális munkások adhatnak a szülőknek nyújtott segítséggel.

Hosszú távon is segítséget jelent, ha az iskolai szociális munkás időben felismeri, hogy egy gyerek veszélyben van és segítségnyújtóan beavatkozik a folyamatba. Az iskolai sikerességnek hosszú távú hatásai vannak: a jövőben biztosabb állást, magasabb jövedelmet remélhetnek azok, akik ma az iskolában jól teljesítenek. Az iskolából kimaradók többsége szegény családban él, és közülük sokan lesznek munkanélküliek. Ezzel együtt az érettségit vagy szakmát nem szerzett 15-24 éves fiatalok 7 százaléka az Egyesült Államokban kimarad az iskolából. Az elmúlt évtizedekben több figyelem irányult azokra a gyerekekre, akiknél a kimaradás veszélye fenyeget: akik több évfolyammal lemaradtak azonos korú társaik mögött, gyengék voltak a tanulmányi eredményeik, és gyakran hiányoztak az iskolából vagy tanév közben váltottak iskolát.

Huffman kiemeli, hogy a megfelelő beavatkozások érdekében pontosan meg kell határozni, melyek a veszélyt jelző indikátorok. Korábban a gyenge anyanyelvi és a matematikai eredményeket, a család rossz társadalmi-gazdasági helyzetét tekintették ilyen mutatónak. Ha egy gyerek elkezdett rosszul teljesíteni ezekből a tárgyakból, értekezletet tartottak és tervet készítettek arra nézve, hogyan segítsék. Azokban az iskolákban, ahová sok veszélyeztetett gyerek járt, plusz pedagógusokat, segítőket alkalmaztak.

A családok azonban az utóbbi időszakban átalakultak, sok - a nukleáris családtól eltérő szerkezetü - családnak több támogatásra van szüksége. Emiatt több szociális munkást alkalmaznak az iskolában, több iskolapszichológust, a pedagógiai munkát támogató tanácsadót. A családformák pluralizálódása tömeges jelenség, az iskolák többsége azonban nincs felkészülve erre a kihívásra.

Az egyszülős családok aránya az összes családon belül egyre magasabb - egy részük nem is volt házas, más részük elvált, külön él a párjától vagy megözvegyült, és sok családban az egyik szülö a munkája miatt él távol a családjától. A gyerekekről sokszor nagyszülök vagy bébiszitterek gondoskodnak. A válások magas aránya, az egyedülálló nők gyerekvállalása, az általuk történő örökbefogadások mind lehetséges magyarázatai ennek a jelenségnek.

Az egyszülős családok szegénységi kockázata lényegesen magasabb. Azoknál a gyerekeknél, akik átélik a szülők válását, különélését, sokkal magasabb a tanulási problémák aránya is. Alacsonyabb az önértékelésük, gyakrabban van probléma a viselkedésükkel. A hosszú távú hatások között megemlítendő, hogy az egyszülős családokban élő gyerekek alacsonyabb végzettséggel fejezik be az iskolát, ami növeli a felnőttkori szegénység kockázatát. 
A kevesebb szülői erőforrás miatt ezek a gyerekek sokszor hiányoznak az iskolából, viselkedésükre kevésbé figyel oda a szülő; magasabb arányban fordulnak elő náluk olyan problémák, mint a figyelemhiány, dührohamok, hazudozás, lopás.

A szülők közötti konfliktusok esetén gyakrabban fordulnak elö a gyereknél mentális problémák: agresszió, szorongás, depresszió, öngyilkosság. Az iskolák azok a lakóközösségben folyamatosan jelenlévő intézmények, ahol mentálhigiénés segítséget lehet felajánlani a gyermekvédelmi rendszer keretében.

A nukleáris (szülőkből és gyerekekből álló) család többé már nem normatív családforma. A tanároknak tudniuk kell, hogy sok gyerek él egyszülős családban, nem vér szerinti szülővel és testvérekkel. Sokszor az iskolai szociális munkás szerepe az, hogy segít a szülőnek, hogy hatékonyan tudjon kommunikálni a gyerekével, megtanítja a társadalom által elfogadott fegyelmezési technikák alkalmazására. Néha a szülők közötti konfliktus megjelenik az iskolában is, ilyen esetben is az iskolai szociális munkás fontos közvetítő, mediáló szerepe lehet.

Sokszor a tanárok nem értik meg az elfogadhatatlan viselkedés okát, nem ismerik fel ennek családi hátterét. A pedagógusok többsége nincs felkészülve azoknak a problémáknak a kezelésére, melyeket sokféle családi probléma: különélés, válás, újraházasodás okozhat, illetve amelyek azzal állnak összefüggésben, hogy a gyereket nem a vér szerinti szülei nevelik. A tanároknak és az iskola vezetöinek fel kell ismerniük ezeket a helyzeteket, és forrásokat keresniük ahhoz, hogy megfelelő segítséget biztosíthassanak ezeknek a gyerekeknek is, hogy a többiekkel azonos esélyekkel rendelkezzenek iskolai pályafutásuk során.

Az Egyesült Államokban 2012 óta a következő szolgáltatásokat nyújthatják szociális munkások az iskolákban ${ }^{1}$ : tanácsadás, krízisintervenció; esetmenedzsment (olyan szolgáltatások összehangolása vagy hozzáférés biztosítása, melyek a gyerekek sikeresebb iskolai részvételét, jobb teljesítményét támogatják); segítségnyújtás tanároknak olyan beavatkozások megtervezésében, melyek a gyerekek viselkedését pozitívan befolyásolhatják. A szociális munkás családokkal, gyerekekkel és a helyi lakóközösség tagjaival dolgozik a gyerekek iskolalátogatásának elösegítése érdekében, közremüködik olyan akadályok elhárításában, mint például a hajléktalanság, közlekedési nehézségek, betegség, fóbia, a szülők iskolával kapcsolatos negatív attitüdjei. A családlátogatások során otthoni környezetben találkozik azokkal, akiknek szociálismunka-szolgáltatásokra van szükségük, a jóléti ellátások, gyermekvédelmi és helyi szolgáltatások igénybevételének elősegítése érdekében.

Az iskola munkatársai mindennapos tevékenységük során találkoznak a gyerekekkel és sokszor a szülőkkel is, és a gyermek veszélyeztetettségének gyanúja esetén kötelességük jelzést tenni a gyermekvédelemnek. Jeffrey McCabe (2018) szerint azonban keveset tudunk arról, hogy milyen módon készülnek az iskolában azok az interjúk, melyek a gyermekvédelmi felmérés részeként készülnek, hogyan müködnek együtt ilyen helyzetekben az iskola és a gyermekvédelem munkatársai. Cikkében ezt a kérdéskört járja körül.

1 Library of Congress. 2012. Bill text: 112th Congress (2011-2012) H.R.1138.IH. http://thomas.loc.gov/cgi-bin/query/z?c112:H.R.1138.IH (utolsó megnyitás: 2018. augusztus 13.). 
JEFFREY McCABE (2018) - Az iskolában készült gyermekvédelmi interjúk

A gyermekvédelem munkatársai az Egyesült Államokban szülői engedély nélkül is kapcsolatba léphetnek a gyerekkel, ha elhanyagolás vagy bántalmazás gyanúja merült fel. Ez az alapelv egységes, viszont sok részletet tekintve eltér az egyes államokban az erre a helyzetre vonatkozó szabályozás. Van, ahol a gyerekkel csak akkor készülhet a szülő tudomása nélkül a lehetséges bántalmazás kivizsgálása céljából interjú, ha a gyerek hazatérve veszélynek lenne kitéve, vagy ha saját maga kéri, hogy a szülő tudomása nélkül hallgassák meg. Eltérések vannak abban is, hogy meg kell-e próbálni a szülö beleegyezését még az interjú előtt megszerezni; amennyiben ez nem lehetséges, akkor egy elfogulatlan, nem érdekelt felnőttnek is jelen kell lennie az interjún, és hatósági felhatalmazás is szükséges a lefolytatásához. Az iskola munkatársai nem feltétlenül vesznek részt az interjún, ha igen, akkor inkább azért, hogy a gyerek számára ismerős, támogató környezetet biztosítsanak. Az iskola mint helyszín azért fontos, mert itt kisebb befolyással lehet a gyerekre a lehetséges elkövetö - aki bizonyos esetekben a szülő. Az iskola ezekben az esetekben csak közvetítő szerepet játszik. A jelenlegi, magyarországi helyzet szempontjából nagyjából mindegy, hogy melyik állam hogyan döntött, sokkal inkább azok a szempontok lehetnek fontosak számunkra, amelyeket mérlegeltek, ezért inkább ezeket emelem ki.

McCabe tanulmányában dokumentumelemzéssel vizsgálja, hogy az egyes államokban hogyan szabályozzák az iskolában készülő gyermekvédelmi interjúval kapcsolatos kérdéseket: kell-e hozzá külső engedély, lehet-e rögzíteni az interjúkat, mennyiben tér el az állami, illetve a magániskolák szabályozása ezen a téren, a szülőket hogyan kell tájékoztatni az interjú elkészültéröl. A gyerekkel minden esetben közölni kell, hogy önkéntesen vesz részt az interjún, és bármikor jelezheti, ha be akarja fejezni. 14 éves kortól a gyerek beleegyezése is szükséges, enélkül nem kerülhet sor az iskolában az interjúra.

Néhány államban a gyerek elutasíthatja, hogy az iskola munkatársai közül bárki jelen legyen az interjún; a beleegyezését minden esetben kérni kell. Van, ahol az iskola érintett munkatársaival külön erre az esetre szóló titoktartási nyilatkozatot íratnak alá és felhívják a figyelmüket, hogy adott esetben tanúskodniuk kell a bíróságon. Néhány államban teljes mértékben a vizsgálatot lefolytató szervezet van felhatalmazva a körülmények meghatározására, és az is előfordulhat, hogy a titoktartás biztosítása érdekében az iskola munkatársai közül senkit nem engednek be az interjúra. A kivizsgálást lefolytató személynek azonban legkésőbb az interjú után kapcsolatba kell lépnie az iskola erre kijelölt munkatársával, hogy a szükséges lépésekről tájékoztassa.

Az iskola vezetőjének írásban nyilatkoznia kell arról, hogy hozzájárul ahhoz, hogy az interjúra az iskola területén kerüljön sor. Ugyanígy az interjút készítő személynek is igazolnia kell az iskola vezetője előtt, hogy felhatalmazása van az eset kivizsgálására. A magániskoláknak joguk van megtagadni, hogy területükön ilyen interjú készüljön, de ha beleegyeznek, akkor nem kell hozzá szülői jóváhagyás. Ha az iskola ragaszkodik ahhoz, hogy egy munkatársa jelen legyen az interjún, akkor a kivizsgálást végző személynek értesítenie kell erről a tényről munkahelyi felettesét.

A gyermekvédelmi intézmények abban az esetben indítanak vizsgálatot, ha olyan bejelentés érkezik, mely elégségesen alátámasztja az elhanyagolás vagy bántalmazás gyanúját. Mivel mindenki tehet ilyen bejelentést, az első lépés a nem hiteles információk kiszürése. Ha vizsgálat indul, akkor ez ellen a szülők panaszt emelhetnek. 
A következő kérdéseket kell McCabe szerint az ilyen esetekben elsősorban mérlegelni: 1. Hogyan kerülnek kapcsolatba az iskolával a gyermekvédelem munkatársai, hogy az első interjút elkészítsék? 2. Milyen beleegyezések szükségesek ahhoz, hogy egy gyerekkel az iskolában interjú készülhessen? 3. Ki lehet jelen ezen az interjún? Milyen együttmüködésnek kell lennie ebben a helyzetben az iskola munkatársai és a gyermekvédelem között?

$\mathrm{Az}$ interjút sok államban lehetőleg video-, de legalább hangfelvételen rögzíteni kell. Dokumentálni kell azt is, hogy miért kellett az iskolában elkészíteni az interjút. Amennyiben a veszélyeztetés gyanúja nem igazolódik az interjú alapján, a gyereknek vissza kell térnie az osztályba. Amikor egy veszélyeztetési eset lezárul, az iskolának az erre vonatkozó iratanyagot meg kell semmisítenie. Az iskolában dolgozó segítő szakemberek felkészítést kapnak, hogyan viselkedjenek, mit tegyenek ilyen helyzetben, ugyanakkor a pedagógusok nem rendelkeznek ilyen jellegü felkészültséggel - ebben az iskolai szociális munkások feladata segítséget nyújtani pedagógus kollégáiknak.

KIRSTEN OGILVIE STALKER - RICHARD BRUNNER - ROSEANN MAGUIRE JUNE MITCHELL (2011): A tartós betegséggel élő és fogyatékos szülők részvétele gyermekeik iskoláztatásában

Az Egyesült Királyságban az állam támogatja a szülők részvételét gyermekük oktatásában, ugyanakkor a szerzők szerint fontos hiány, hogy a tartós betegséggel, fogyatékossággal élő szülők nem minden esetben kapnak külön segítséget ehhez. Az ottani esélyegyenlöségi törvény szerint proaktívan segíteni kell a fogyatékos emberek társadalmi részvételét; a kérdés az, hogy miként lehet az előttük álló akadályokat ezen a területen is minél inkább lebontani. A tanulmány kifejezetten a fogyatékossággal vagy tartós betegséggel élő szülők nehézségeire koncentrál, segíteni kívánja annak megértését, hogy milyen nehézségekkel szembesülnek a gyerekeik iskolai életében történő részvétel során.

Az iskolai szociális munkások speciális feladata a tartós betegséggel, fogyatékossággal élő szülők támogatása abban, hogy részt vehessenek ugyanazokban a tevékenységekben gyerekeik oktatásával kapcsolatban, mint nem sérült szülőtársaik. Viszonylag sok kutatás foglalkozik a hátrányos helyzet, az etnikai háttér és a szülök iskolai részvételének összefüggéseivel, ugyanakkor alig vizsgálták a tartós betegséggel vagy fogyatékossággal élő szülők helyzetét ebből a szempontból, holott ez a szülök 11 százalékát érinti az Egyesült Királyságban.

A szerzők szerint a szülő aktív részvétele gyerekük iskoláztatásában összefüggést mutat a jobb iskolai eredményekkel, előnyös mind a szülő, mind a gyerek, mind az iskola számára. Statisztikai szempontból a 7 és 16 éves kor közötti gyerekeknél a szülök iskolázottsága, a család helyzete, nagysága, határozzák meg legerősebben a gyerek iskolai eredményességét, nyelvi és számtani készségeit. Más szerzők szerint csak az otthoni tanulásnak van ilyen hatása, az iskolai programokban való szülői részvétel inkább a gyerek társas skilljének kibontakozását segíti.

Fontos, hogy az iskolák segítsenek a szülöknek abban, hogy miként tudják a legjobban támogatni gyerekeik otthoni tanulását. Az anyák pszichoszociális egészsége erősen befolyásolja a gyerek iskolai teljesítményét, az anyai depresszió például akadálya lehet a szülő iskolai részvételének. A fogyatékossággal vagy tartós betegséggel élő szülők azonban 
gyakran jelzik az oktatási hatóságoknak, hogy szeretnének részt venni gyerekeik iskolai életében.

A fogyatékosságot korábban egyéni rendellenességnek tartották, ezzel szemben a fogyatékosságtudomány a társadalmi, környezeti akadályokat hangsúlyozta; ebben a tanulmányban a szerzők a kettő kölcsönhatására irányítják a figyelmet. A fogyatékos szülőkre eddig kevés figyelem irányult, mivel úgy tekintették őket, mint akikről gondoskodni kell, nem úgy, mint akik gondoskodnak másokról, például a gyerekeikröl.

A tanulmány áttekinti az Egyesült Királyság szakpolitikáit, az eddigi kutatási eredményeket a fogyatékos szülők iskolai részvétele szempontjából. A bemutatott kutatás feltárja, milyen tapasztalatokat szereznek gyerekük oktatásával kapcsolatban, elsősorban a jó gyakorlatokat fókuszba helyezve; kiemeli az akadályok elhárítását és a részvételt segítő folyamatokat. A megkérdezett szülőket civil szervezetek ügyfelei közül toborozták; elsősorban olyanokat kerestek, akiknek már volt tapasztalatuk valami jó gyakorlattal kapcsolatosan, így a minta nyilvánvalóan nem reprezentálta a fogyatékossággal élő szülők alapsokaságát.

A megkérdezett szülők között volt mozgáskorlátozott, érzékszervi fogyatékos, értelmileg akadályozott és egyéb mentális problémával élő személy (utóbbiakat volt a legnehezebb bevonni a kutatásba). A végső mintába 23 szülő került, többnyire anyák, csak négy apa és egy olyan nagymama, aki unokájának elsődleges gondozója volt. Két szülő mindkét fogyatékossági csoportba is besorolható volt. Ez a tanulmány elsősorban a szülöi tapasztalatokra fókuszált, de néhány olyan tanárral, pedagógiai asszisztenssel, gyermekjogi képviselővel is készült interjú, akik nagyon sokat segítettek fogyatékossággal élő szülőknek a gyerekük iskolai részvételében.

A tanulmány készítése során fogyatékossággal élő szülőket kérdeztek meg azokról a nehézségekröl, amelyeket átélnek, nem csak a gyerekeik oktatásával kapcsolatban. A szülök megfogalmazták, hogy iskolai részvételüket gyakran nehezíti az iskola nem teljes körü akadálymentesítése; az, hogy szülői értekezleteken való részvételükhöz külön segítségre lenne szükségük. Olykor nehézséget jelent az iskola egyes munkatársainak elöítéletessége, valamint az, ha a gyerek iskolai elhelyezése során a szülő fogyatékosságát nem veszik figyelembe. Néhány szülő beszámolt arról, hogy szociális szervezetek és az iskola együttmüködése segítette részvételét gyermeke iskolai életében.

A szülői részvételnek három szintjét különböztették meg: az első volt a házi feladat elkészítésében való segítségnyújtás, a második az iskola életében, eseményeiben való részvétel, a harmadik a különféle iskolai testületekben vállalt szerep.

A jó gyakorlatok között szerepelt például olyan eset, mikor a gyengénlátó apának olyan formátumban küldték el a fia házi feladatát, hogy segíteni tudja a gyereket az otthoni tanulásban. Egy másik iskolában megfelelő körülményeket alakítottak ki ahhoz, hogy egy kerekes székes szülő részt tudjon venni a gyerekek kézmüves-tevékenységében. Egy gyengénlátó apa az iskolaszék tevékenységében vett részt az igazgató ösztönzésére. Néhány fogyatékos szülő önbizalmát kifejezetten emelte az iskolai eseményeken való segítő részvétel, habár ez sokkal nehezebb volt számukra, mint ép szülőtársaiknak. Olykor a szülőt kérték meg, hogy a gyermekét leginkább ismerö felnőttként ő adjon tanácsot a pedagógusoknak a gyermek szokásaival kapcsolatban. 
A szülői részvétel korlátainak lebontása érdekében fontos a mindenki számára érthető, informális kommunikáció. Egy gyengénlátó anyának az segített, hogy az óvodát még a nyitás előtt végigjárhatta és megismerhette a teret, mikor még nem voltak benn a gyerekek. Olykor a minden szülö részvételét elősegítő gyakorlatok bizonyultak különösen nagy segítségnek a fogyatékos szülők számára. A mentális zavarokkal élő, otthonról nehezen kimozduló szülők számára például jó alkalom a kapcsolatteremtésre a családlátogatás. Azoknak a szülőknek, akiknek rossz emlékeik vannak saját iskolai múltjukról, különösen sokat segít, ha a pedagógus vagy az iskola egy másik munkatársa könnyen elérhető számukra - például iskolakezdés előtt vagy a tanítás befejezése után tudnak vele pár percet beszélni.

Néhány szülőnek nehézséget okozott, hogy beszéljen az iskolában a saját fogyatékosságáról: tartott attól, hogy emiatt másképp fogják kezelni a gyereket. Fontos, hogy a szülö saját maga határozhassa meg, milyen segítségre van szüksége az iskola részéről, ne az iskolai dolgozók elöfeltevéseire alapuljon a felajánlott segítség. Különféle álláspontok fogalmazódtak meg azzal kapcsolatosan, hogy az iskolában dolgozó munkatársak közül kinek kell tudnia a szülö fogyatékosságáról, speciális kommunikációs igényéről: mindenkinek vagy csak a közvetlenül érintett munkatársaknak, esetleg egy speciális koordinátornak. A befogadás etikája szerint mindenki feladata az esélyegyenlőség szolgálata, ugyanakkor a szülö joga, hogy eldöntse, kivel osztható meg a rá vonatkozó személyes információ.

STEVEN LAWRENCE, Jr. - HANNAH MECKLEY-BREWER - PHILIP M. STINO (2017): Az iskolai zaklatás előrejelzése és megelözése

Az iskolai zaklatásnak (bullying) tekinthetünk bármilyen agresszív, zaklató viselkedést, ami időről időre ismétlődik, lehet az szóbeli, érzelmi vagy fizikai természetü, és összekapcsolódhat vélt vagy valódi hatalmi alá-, illetve fölérendeltséggel. Az áldozatok próbálnak távol maradni, nem elköteleződni, ami könnyen azzal végződhet, hogy kimaradnak az iskolából. Más gyerekek éppen az iskolai zaklatás miatt félnek iskolába menni, holott joguk lenne jól és biztonságban érezni magukat. A zaklatást átélő gyerekeknek gyakran alacsony az önbizalmuk és nem bíznak másokban. Az iskolai zaklatás szorongást, depressziót válthat ki, legrosszabb esetben öngyilkossághoz is vezethet.

Nincs egyetlen hatékony stratégia az iskolai zaklatás megelőzésére, viszont az egész iskolának közre kell müködnie benne. Az iskolai zaklatás valamilyen formája a gyerekek 20 százalékát érinti. A bünelkövetési statisztikák csökkentek ugyan, de az iskolai zaklatás szintje nem változott. Ezért fontos beazonosítani a veszélyeztetett csoportokat és a megelőzésbe a szülöket is bevonni.

A prevenciós programok megtervezésénél fontos tudni, hogy van-e jelentősége az adott iskolában annak, hogy milyen messziről utazik a gyerek az iskolába, részt vesz-e iskola utáni programokon, milyen biztonsági intézkedések vannak az iskolában, hogyan érzékelik a gyerekek az iskolai szabályokat, milyen gyakran fordulnak elö az iskola környékén büncselekmények, mennyire van jelen a drog, vannak-e bandák a környéken. Ezeknek a tényezőknek a felmérésében az iskolai szociális munkás kulcsszerepet játszik.

A legerősebb előjelzője az iskolai bántalmazásnak az osztályban való elkülönülés, valamint az, hogy a gyerek már sok veszekedésben vagy verekedésben vett részt. Ugyanígy a gyülöletet kifejező szavak vagy jelképek is előre mutathatják a bántalmazás valószínüségét. 
Így az elkülönülő gyerekek bevonása, a gyülölet bármilyen formájára való megfelelő reakció, az iskolai zaklatást megelőző programok, a biztonságos iskolai légkör megteremtése az iskola valamennyi munkatársának közös felelőssége. Ugyanilyen fontos a szülök tájékoztatása, támogatásának megnyerése, ami ismét fontos feladata az iskolai szociális munkásnak.

SUSAN I. STONE - JESSICA CHARLES (2018): Az iskolai szociális munka hangsúlyai az interprofesszionális és a szülőkkel történő együttmüködésben

Az interprofesszionális együttműködés a szociális munkás egyik legfontosabb skillje, ami az iskolai szociális munkában is központi jelentőségü; ugyanígy a szülőkkel való kapcsolatteremtés, valamint a szülők és szakemberek közötti együttmüködés kialakításának segítése is. Klasszikus iskolai szociálismunkás-feladat a folyamatok összehangolása, a hagyományos szakmai határok áthidalása, az egyes szakmák által kitüzött célok közös tevékenységgé alakítása, a szolgáltatások integrációja - és mindennek a szülőkkel történő megismertetése, támogatásuk megszerzése. Kérdés azonban, hogy mi az, amit az egyes szociális munkások fontosnak tartanak, milyen szerepeket játszanak a segítés folyamatában.

A szerzők egy valóságos elemekböl konstruált, képzeletbeli esetről kérdeztek meg iskolai szociális munkásokat írásban. A megkérdezettek egy közeli egyetem MA-szinten, iskolai szociális munka szakon végzett hallgatói voltak; összesen 70 válasz érkezett. A szerzők azt kérdezték az iskolai szociális munkásoktól, hogy miként támogatnák a fiktív esetleírásban szereplő fiút - ezzel elsősorban azt szerették volna megtudni, hogy a válaszadók hova teszik a hangsúlyt, összetett feladatrepertoárjukból miket emelnek ki, mire kerül a hangsúly. Kérdésük az volt, hogy meg lehet-e különböztetni jól eltérö különbségeket a válaszolók szerepfelfogásában, meg lehet-e ragadni elkülönülő mintázatokat.

A fiktív esetben egy 9 éves, spanyol ajkú fiúval kapcsolatban kérte az osztályt tanító pedagógus az iskolai szociális munkás segítségét. A család nemrég érkezett az Egyesült Államokba, a gyerek visszahúzódó, lassan tanul angolul, nem vesz részt az osztály életében, órák alatt a fejét a padra hajtja. Édesanyja kíséri minden reggel az iskolába. Az anya nem engedi a gyereket ki az utcára a társaival játszani, mert fél a helyi fekete bőrü gyerekektől. Ha a fiú más spanyol ajkú gyerekekkel vagy felnőttel van együtt, abban a helyzetben bőbeszédü, humoros. Az iskolai szociális munkás osztálytermi megfigyelést végzett, ekkor egy olyan jelenet játszódott le, hogy a fiú társai poénkodtak azon, hogy nem tud semmit; de nem volt világos, hogy a fiú érti-e, hogy róla van szó. A tanár átsiklott ezen a problémán, nem foglalkozott az esettel, folytatta az elkezdett matematikapéldát.

A megkérdezett iskolai szociális munkások mindegyike említett három, más szakmához tartozó kollégát, és összesen kilenc felnőttet, akit be kellene vonni az esetbe. A szakemberek közül legtöbben az osztályt tanító pedagógust, az igazgatót, az iskolapszichológust nevezték meg, de sokan gyógypedagógust, nyelvtanárt, logopédust is megkerestek volna. A családdal minden válaszadó felvette volna a kapcsolatot.

A válaszok elemzése alapján az iskolai szociális munkában a következő szerepfelfogások jelentek meg: 1. A kezdeményezö/koordinátor a családot, a tanárt, a gyereket összekötné az iskolában, ill. helyben elérhetö forrásokkal; elsősorban a felnőttekkel kezdeményezne beszélgetést a gyerek szükségleteinek feltérképezése érdekében. Nem feltétlenül létesítene közvetlen kapcsolatot a gyerekkel és nem követné az eseményeket, inkább a források elérése, 
a szálak összekötése lenne az elsődleges számára. 2. A feltérképezőnél a különféle forrásokból szerezhető információk összegyüjtésén volt a hangsúly; ezeket a válaszadó megosztotta volna az érintett felnőttekkel, és velük együtt tervet készített volna a gyerek segítésére. Sokszor ez a szerep átváltott a kezdeményező szerepbe. 3. A beavatkozó közvetlen kapcsolatot vett volna fel a gyerekkel és meghatározott tevékenységekbe vonta volna be, mások a pedagógussal vagy a gyerek családjával építettek volna ki kapcsolatot a gyerek segítése érdekében. 4. A szóvivő felhívná az illetékesek (pl. az igazgató) figyelmét a gyerek helyzetére. 5. Az együttmüködö a tanár és a többi szereplö kapcsolatával foglalkozna leginkább.

A válaszok jól mutatták, hogy a válaszadók mennyire másképpen konstruálták meg az esetet, mennyire mást és mást tartottak legfontosabb feladatuknak. A szerzők ebből azt a következtetést vonták le, hogy az egyik legfontosabb feladata az iskolai szociális munkásnak az, hogy segítsen az érintetteknek - például esetkonferencia formájában - olyan közös gondolati keretet kialakítani, melyben céljaikat egymáshoz illeszkedve határozhatják meg; tevékenységük eredményeit ennek függvényében értékelhetik a későbbiekben.

\section{KATIE COTTER STALKER (2018): Kortárs bíróságok (Teen court modell)}

Az iskolából való kitiltás olyan büntetés, melyet nagy valószínűséggel követ valamilyen fiatalkorú büncselekmény, ill. később a bebörtönzés, ahogy az angol nyelvü szakirodalom említi, school-to-prison pipeline (STPP). Nagy kihívás a szociális munkásoknak, hogy olyan, arányos fegyelmezési technikákat találjanak ki, melyek nem idegenítik el az iskolától az iskolai fegyelmet súlyosan megsértő gyereket. Gyakori fegyelmezési módszer, hogy a gyereket rövidebb-hosszabb időre kitiltják az iskolából. Fekete bőrü vagy amerikai őslakos (indián) gyerekek nagyobb arányban kapnak ilyen büntetést, magasabb az arányuk a fiatalkori bünelkövetésben is, ami az életük során további hátrányokat okoz: megbélyegzettséget, stigmát jelent, az életesélyek jelentős csökkenését, a felnőttektől való eltávolodást. Ezért fontos, hogy a tanárok ismerjék a különféle kultúrákból származó gyerekek értékrendszerét, elköteleződjenek mellettük - ebben a szociális munkásoknak fontos feladatai lehetnek.

A teen court modell alternatívája lehet az iskolából való kitiltásnak vagy eltanácsolásnak. Az eljárást fiatalkorú bünelkövetőknél szokták alkalmazni első büncselekmény esetén; bíróság rendelheti el a részvételt, elterelésként. A teen court modell előnye, hogy nem az igazságszolgáltatás procedúrája szerint zajlik a folyamat, hanem egy kortársakból álló kvázi bíróság tárgyalja az ügyet. Néhány modellben a bíró felnőtt, másokban szintén tizenéves. Minden esetben a tizenéves 'esküdtek' hozzák meg a döntést a következményeket, ill. szankciót illetően, ami lehet közösségi szolgálat is, pl. ugyanilyen ügyekben esküdtként részt kell venni vagy bocsánatkérő levelet kell írni stb. Ha a fiatal nem teljesíti, amit ilyen módon előírtak számára, akkor visszakerül az ügy a szokásos vágányra, az igazságszolgáltatáshoz.

A teen court modell a helyreállító igazságszolgáltatás modelljeit is felhasználja: azt hangsúlyozza, hogy a törvényszegő viselkedés veszélyeztet más embereket, emberi kapcsolatokat. Gyakran alkalmaznak olyan eljárásokat, hogy az elkövetőnek beszélnie kell a 
sértettel vagy azzal, akinek kárt okozott, meg kell javítania, amit elrontott vagy meg kell fizetnie a kárt stb.

Az ezzel kapcsolatos kutatások elsősorban arra fókuszálnak, hogy elkerülhető-e ilyen módon a bünismétlés. A szerző szerint az eddigi eredmények biztatóak: a hagyományos igazságszolgáltatási eljárásokkal szemben a teen court modellben részt vevőknél kisebb arányban találtak bünelkövető barátokat, agressziót, internalizáló tüneteket.

Ezek a programok inkább helyi, közösségi szinten müködnek, kevésbé az iskolákban. Egy részüket csak igazságszolgáltatási szervek kezdeményezhetik, a büntetőeljárás alternatívájaként. Más programok iskoláktól is fogadnak eseteket. Előzőekben iskolán kívüli problémákkal, utóbbiban inkább iskolaiakkal foglalkoznak, de ezek között előfordulnak olyanok is, melyek az igazságszolgáltatásban folytatódnának a teen court modell alkalmazása nélkül. Mindegyik modellben a hagyományos büntetésekkel szemben alternatív megoldásokat keresnek. A lakóközösségben elérhető és az iskolai eljárások közötti együttmüködésben további lehetőségek rejlenek.

Van néhány olyan alapfeltétel, amelynek a teen court modell alkalmazása során teljesülnie kell, ezek a következők: 1. titoktartás (nem lesz pletyka abból, ami itt elhangzik); 2. az elkövetett cselekmény beismerése (ez nem olyan bíróság, mely megállapítja, hogy az elkövetö ártatlan-e vagy bünös); 3. a szülök engedélye (néhány programban megkövetelik a szülő részvételét is); 4. szakmai hozzáértés és a résztvevők előzetes felkészítése; 5 . tanúkat nem hallgatnak meg; 6. konstruktív módon határozzák meg a következményeket, melyekböl tanulhat az elkövető, reflektálhat arra, amit tett; 7. reális időkeretet határoznak meg; 8. a következményeknek, az elvárásoknak teljesíthetőeknek kell lenniük; 9. a teljesítést ellenőrzik; 10. az iskola vezetése támogatja a programot, küld eseteket és elfogadja a kortárs bíróság által meghatározott következményeket. Az iskolának e feltételek betartásával joga van kialakítani a saját kortársbíróság-modelljét, ami a legjobban illik az oda járó gyerekek sajátosságaihoz.

Az iskolai szociális munkás szerepe a kortársbíróság-modell és az iskola közötti kapcsolatban rendkívül sokrétü. Egyrészt megismertetheti a különféle, a közelben elérhető modelleket az iskola munkatársaival, beszélgetést kezdeményezhet arról, hogy ezek közül melyik felelne meg leginkább az adott környezetben; az iskola kapcsolódhat egy már müködő teamhez vagy kialakíthat saját programot. Az iskolavezetés elköteleződése döntő fontosságú, így a folyamat kezdetén nyíltan kell beszélni arról, hogy ki mit vár tőle, milyen fenntartásai vannak stb.

Ha az iskola úgy dönt, hogy bevezetik a kortársbíróság-modellt, az iskolai szociális munkásnak kulcsszerepe lehet olyan beszélgetések lefolytatásában, melyek során az alapvető szabályokban megegyeznek, pl. ki küldhet esetet, milyen természetúek lehetnek a szankciók vagy következmények, ki fogja irányítani a felkészülés folyamatát, kiválasztani és felkészíteni a gyerek 'ügyészeket'. Szintén feladata az iskolai szociális munkásnak a kialakuló együttmüködés vagy az új program értékelése. Fontos, hogy a program az egyedi körülményekhez alkalmazkodjon, de emiatt a hatékonyságát is rendszeresen ellenőrizni kell. A szociális munkás szerepe, hogy a resztoratív igazságszolgáltatás kultúráját meghonosítsa az iskolában. Különösen fontos lehet ez olyan iskolákban, melyeket magasabb arányban látogatnak színes bőrü, hátrányos helyzetü diákok - öket általában többször zárják ki vagy tanácsolják el az iskolából; a kortársbíróság-modell ritkábban van jelen azokban az iskolákban, ahol ők magasabb arányban vannak jelen. 
Mielőtt a program bevezetésre kerül, a résztvevőket meg kell ismertetni a resztoratív igazságszolgáltatás alapelveivel, azzal, hogy ennek lényege a jóvátétel, a kapcsolatok helyreállítása; nem elég csak a hagyományos bírósági szerepeket gyerekekre osztani. Az iskola munkatársaival végig kell gondolni, hogyan akadályozható meg, hogy gyerekeket megbélyegezzenek, megszégyenítsenek a folyamat során. Emiatt például nem elkövetőröl, hanem résztvevőröl beszélnek.

A szülök informálása, támogatásuk megnyerése szintén nagyon fontos feladat. A resztoratív igazságszolgáltatás lényegének megértése és elfogadása itt is alapvető, különben a sértett gyerek szüleinek igazságkeresése alááshatja a kortárs bíróságok munkájának hatékonyságát.

\section{IRODALOMJEGYZÉK}

BREWER, Jr., S. L., MECKLEY-BREWER, H., STINSO, P. M. (2017): Fearful and Distracted in School: Predicting Bullying among Youths. Children and Schools, Volume 39 Number 4 October 2017.

COSTIN, F. (1975): School social work. Social Work, March.

A Háló c. folyóirat Iskolai szociális munka tematikus száma, 2008/3. http://halo.3sz.hu/sites/default/files/uploaded/2008_marcius.pdf (utolsó megnyitás: 2018. augusztus 13.).

HUFFMAN, A. M. (2013): Students at Risk Due to a Lack of Family Cohesiveness: A Rising Need for Social Workers in Schools. The Clearing House, 86: 37-42, Routledge, Taylor \& Francis Group.

McCABE, J. (2018): Child Welfare Interviews at School: A Review of Statues and Policies. Child and Adolescent Social Work Journal, 35. 337-355. https://doi.org/10.1007/s10560018-0535-7 (utolsó megnyitás: 2018. augusztus 13.).

STALKER, K. C. (2018): Teen Court-School Partnerships: Reducing Disproportionality in School Discipline. Children and Schools, Volume 40, Number 1, July.

STALKER, K. O., BRUNNER, R., MAGUIRE, R., MITCHELL, J. (2011): Tackling the barriers to disabled parents' involvement in their children's education. Educational Review, Vol. 63, No. 2, May. 233-250.

http://www.informaworld.com (utolsó megnyitás: 2018. augusztus 13.).

STONE, S. I., CHARLES, J. (2018): Conceptualizing the Problems and Possibilities of Interprofessional Collaboration in Schools. Children and Schools, Volume 40, Number 3, July. 